\title{
Zinc and Respiratory Viral Infections: Important Trace Element in Anti-viral Response and Immune Regulation
}

\author{
Fatemeh Sadeghsoltani ${ }^{1} \cdot$ Iraj Mohammadzadeh $^{2} \cdot$ Mir-Meghdad Safari $^{3} \cdot$ Parisa Hassanpour $^{1} \cdot$ Melika Izadpanah $^{4}$. \\ Durdi Qujeq $^{5,6} \cdot$ Soheila Moein ${ }^{7} \cdot$ Mostafa Vaghari-Tabari $^{1,8}{ }_{(\mathbb{C}}$
}

Received: 29 April 2021 / Accepted: 28 July 2021 / Published online: 9 August 2021

(c) The Author(s), under exclusive licence to Springer Science+Business Media, LLC, part of Springer Nature 2021

\begin{abstract}
Influenza viruses, respiratory syncytial virus (RSV), and SARS-COV2 are among the most dangerous respiratory viruses. Zinc is one of the essential micronutrients and is very important in the immune system. The aim of this narrative review is to review the most interesting findings about the importance of zinc in the anti-viral immune response in the respiratory tract and defense against influenza, RSV, and SARS-COV2 infections. The most interesting findings on the role of zinc in regulating immunity in the respiratory tract and the relationship between zinc and acute respiratory distress syndrome (ARDS) are reviewed, as well. Besides, current findings regarding the relationship between zinc and the effectiveness of respiratory viruses' vaccines are reviewed. The results of reviewed studies have shown that zinc and some zinc-dependent proteins are involved in anti-viral defense and immune regulation in the respiratory tract. It seems that zinc can reduce the viral titer following influenza infection. Zinc may reduce RSV burden in the lungs. Zinc can be effective in reducing the duration of viral pneumonia symptoms. Zinc may enhance the effectiveness of hydroxychloroquine in reducing mortality rate in COVID19 patients. Besides, zinc has a positive effect in preventing ARDS and ventilator-induced lung damage. The relationship between zinc levels and the effectiveness of respiratory viruses' vaccines, especially influenza vaccines, is still unclear, and the findings are somewhat contradictory. In conclusion, zinc has anti-viral properties and is important in defending against respiratory viral infections and regulating the immune response in the respiratory tract.
\end{abstract}

Keywords Zinc $\cdot$ Influenza viruses $\cdot$ COVID-19 $\cdot$ Respiratory viral infections $\cdot$ Vaccination

\section{Introduction}

Human respiratory viral infections can be considered a major public health problem. High costs are incurred in controlling respiratory viruses' epidemics. For example, influenza viruses cost the US healthcare system about $\$ 87$ billion per

Mostafa Vaghari-Tabari

mostafavaghari@yahoo.com; vagharim@tbzmed.ac.ir

1 Department of Clinical Biochemistry and Laboratory Medicine, School of Medicine, Tabriz University of Medical Sciences, Daneshgah Street, P.O. Box 51666-14711, Tabriz, Iran

2 Non-Communicable Pediatric Diseases Research Center, Health Research Institute, Babol University of Medical Sciences, Babol, Iran

3 Virtual School of Medical Education and Management, Shahid Beheshti University of Medical Sciences, Tehran, Iran year [1]. Influenza, respiratory syncytial virus (RSV), and the emerging SARS-COV2 virus are among the most important respiratory viruses that can cause severe respiratory infections that may be fatal. Although there is limited statistical information, published data suggest that more attention should be paid to the control of respiratory viral infections.

4 Department of Anatomy, Faculty of Medicine, Tabriz University of Medical Sciences, Tabriz, Iran

5 Cellular and Molecular Biology Research Center (CMBRC), Health Research Institute, Babol University of Medical Sciences, Babol, Iran

6 Department of Clinical Biochemistry, Babol University of Medical Sciences, Babol, Iran

7 Medicinal Plants Processing Research Center, Shiraz University of Medical Sciences, Shiraz, Iran

8 Immunology Research Center, Tabriz University of Medical Sciences, Tabriz, Iran 
It is estimated that in 2018 , the influenza viruses caused the deaths of approximately 34,800 children under the age of 5 due to acute lower respiratory infection globally [2]. It has been reported in 2015 that RSV caused approximately 59,600 deaths in children under the age of 5 globally [3]; as well as, it is estimated that this number is about 14,000 in the elderly over 65 years [4]. According to a WHO report, the COVID-19 pandemic has infected over 174.4 million people worldwide, and the number of deaths had totaled more than 3.7 million as of June 10, 2021. Investigating the importance of vitamins and trace elements in diseases of the respiratory system is one of the most interesting research areas. Among the trace elements, zinc has attracted a lot of attention. Zinc is a vital microelement that is essential for a variety of fundamental biological processes due to its function as a transition metal, cofactor, structural component, and signaling molecule [5]. Zinc is an essential trace element, and serum levels between 90.1 and $98.7 \mu \mathrm{g} / \mathrm{l}$ of zinc are considered optimal serum levels [6]. It is estimated that 17 to $20 \%$ of the world's population may be zinc-deficient [7]. Zinc seems to be very important in anti-viral defense and immune regulation in the respiratory tract. A meta-analysis of 13 studies in China revealed that children with recurrent respiratory tract infection had low zinc levels [8]. Some meta-analysis and systematic reviews results showed that zinc could be helpful in decreasing the prevalence and incidence of pneumonia in children [9], reducing mortality rate in adults with severe pneumonia [10], and reducing common cold duration in adults $[11,12]$. Thus, adequate dietary intake of this trace element may be essential for preventing and more effective treatment of respiratory infections.

Zinc has significant anti-viral properties. Zinc anti-viral effects appear to be virus-specific. Zinc can affect a wide range of viruses. For example, zinc has an inhibitory effect on viral polyprotein cleavage in encephalomyocarditis virus. Zinc inhibits viral RNA polymerase and replication in hepatitis $C$ virus. Zinc can inhibit viral DNA polymerase in herpes simplex virus. In addition, zinc can inhibit reverse transcriptase in HIV. Zinc also has interesting anti-viral effects on respiratory viruses. For example, it can inhibit viral polymerase and polyprotein cleavage in rhinoviruses. The inhibitory effect of zinc on SARS-coronavirus (SARS-CoV) replication has also been reported. Zinc may reduce viral titer in RSV infection [7, 13]. In addition, some zinc-dependent anti-viral proteins, including zinc-finger anti-viral protein (ZAP), play an important role in attenuating viral protein expression in influenza and restricting SARS-COV2 [14, 15]. In this article, we review the most interesting findings regarding the zinc's role in the anti-viral immune response and immune regulation in the respiratory tract and discuss the importance of this trace element in defense against influenza, RSV, and SARS-COV 2. Besides, we review the most interesting findings regarding the association of zinc with acute respiratory distress syndrome (ARDS). The effect of zinc on the effectiveness of vaccination, against respiratory viruses, was reviewed, as well.

\section{Method}

The present study is a narrative review. Literature search was performed in PubMed and Google Scholar. Search areas include respiratory viral infections, anti-viral immune response in the respiratory tract, the role of zinc in anti-viral defense and immune regulation in the respiratory tract, the importance of zinc in defense against influenza, RSV and SARS-COV2 infections, the relationship between zinc and ARDS, and relationship between zinc and the effectiveness of respiratory viruses' vaccines. The number of articles founded in the above-mentioned areas was 169. All founded articles were used. No inclusion or exclusion criteria were applied.

\section{Results and Discussion}

\section{Anti-Viral Response in the Respiratory System}

Undoubtedly, reviewing the details of the anti-viral immune response in the respiratory tract requires the writing of a separate review article. However, before beginning the discussion on the importance of zinc in anti-viral defense and immune regulation in the respiratory system, it is necessary to have a very brief overview of the most important events of the anti-viral immune response in the respiratory tract. The anti-viral immune response in the respiratory tract is divided into innate and adaptive immune responses, which work together to eliminate the infection. Respiratory viruses are mainly transmitted through the inhalation of infectious particles. Respiratory viruses enter the epithelial cells of the respiratory tract and replicate inside these cells, eventually leading to the release of new viral particles and the infection of more cells. Respiratory epithelial cells could rapidly detect viral pathogen-associated molecular patterns (PAMPs) and trigger an immune response via pathogen recognition receptors (PRRs) such as NOD-like receptors (NLRs) and toll-like receptors (TLRs) [16]. Activation of interferon regulatory factors (IRF) and NFKB within respiratory epithelial cells leads to the release of type I interferons and pro-inflammatory cytokines such as TNF $\alpha$ [16]. IFN- $\alpha$ and IFN- $\beta$ belong to type I interferons. These interferons can disrupt the replication of viruses and play an essential role in anti-viral defense in the respiratory tract [17]. Some antimicrobial peptides which are produced by the epithelial cells of the respiratory tract also appear to be 
involved in anti-viral defense. Pro-inflammatory cytokines and chemokines such as CXCL8 and CXCL10, which are produced by the epithelial cells of the respiratory tract, enhance the recruitment of immune cells to the site of infection [18]. Neutrophils and macrophages can produce significant amounts of ROS, anti-microbial peptides, and pro-inflammatory cytokines. In addition to cytolytic activity, which is very important in anti-viral defense, NK cells can produce significant IFN- $\gamma$, thereby enhancing the function of cytotoxic T cells $[19,20]$. The adaptive immune response begins with the activation of dendritic cells and the migration of these cells to the draining lymph nodes. Virus-infected epithelial cells play an important role in invoking dendritic cells to the infection site and maturating them by producing chemokines such as CCL2 and types I and III interferons [21, 22].

After migrating to draining lymph nodes, dendritic cells can activate naive $\mathrm{CD} 8+$ and $\mathrm{CD} 4+\mathrm{T}$ cells by presenting viral antigens through $\mathrm{MHC}$ molecules. Activated naive $\mathrm{T}$ cells can differentiate into various $\mathrm{T}$ cells, including effector CD8 + and CD4 $+\mathrm{T}$ cells $[18,21]$. Alveolar macrophages and NK cells may act as antigen-presenting cells, as well [21]. Effector T cells migrate to the site of infection. The secretion of pro-inflammatory cytokines and chemokines by virus-infected epithelial cells and innate immune cells enhances the invocation of $\mathrm{T}$ cells to the area of infection [16]. CD8 + T cells can induce apoptosis in virus-infected cells and play a key role in anti-viral defense in the respiratory tract [23]. Th1 and Th2 are among the effector $\mathrm{CD} 4+\mathrm{T}$ cells that play a crucial role in the immune system and anti-viral defense. These cells can enhance the function of $\mathrm{C} 8+\mathrm{T}$ cells and have a stimulatory effect on the ability of B lymphocytes to produce antibodies [23]. Th1 cells can produce significant amounts of cytokines such as IL2 and IFN- $\gamma$, thereby enhancing the function of NK cells [24]. In fact, a combination of innate immunity, antibody production, and cytotoxic function of TCD8 + cells is involved in anti-viral defense in the respiratory tract, and effector $\mathrm{CD} 4+\mathrm{T}$ cells play an indirect but important role in anti-viral defense by leading these events. In HIV infection, where T CD4 + cells are targeted as the main target, the immune system is significantly weakened, indicating the high importance of these cells in the immune system [25]. Figure 1 summarizes the above-mentioned events.

The critical point is that all these events must occur in a proper and regulated manner; otherwise, excessive inflammation can cause tissue damage. Impaired regulation of the anti-viral immune response in the airways can lead to the sudden production of large amounts of pro-inflammatory cytokines. This event, called a cytokine storm, can be very dangerous [26].

\section{Zinc and Immune Response in the Respiratory System}

Zinc appears to be a key player in anti-viral defense in the respiratory tract. The role of zinc in the immune system can be divided into three categories, namely catalytic, structural, and regulatory functions [27]. Zinc may improve host defense by maintaining the structure and function of the respiratory epithelium barrier. Disorders in the integrity of respiratory epithelium can promote the viruses' entry $[28,29]$. Respiratory tract is constantly exposed to various pathogens; therefore, maintaining the structural integrity of the epithelium is very important in the respiratory system [28]. Zinc depletion in airway epithelial cells disrupted the structural proteins, including $\beta$-catenin and E-cadherin, leading to enhanced leakage across the respiratory epithelial barrier [30]. The expression of ZO-1 and Claudin-1 which are tight junction proteins is also found to be zincdependent [29]. It seems that zinc deficiency can lead to serious changes in lung epithelial barrier function, possibly through up-regulation of IFN $\gamma$ and TNF $\alpha$, enhancement of FasR signaling, and enhancement of apoptosis. In addition, apoptosis and para-cellular leakage can be attenuated by zinc supplementation [30]. One of the most important aspects of anti-viral immune response in the respiratory system is that the immune response must be appropriate and regulated. Although the immune response and the inflammatory process can eliminate pathogens, excessive inflammation can cause tissue damage. Therefore, regulation of inflammation is important, particularly when respiratory cells respond to invading pathogens [31]. It seems that zinc plays a key role in this regard. Inadequate dietary zinc intake can cause $\mathrm{Zn}$ deficiency leading to impaired immune function [32]. Zinc is involved in the regulation, normal growth, and function of immune cells such as monocytes, neutrophils, $T$ and B-lymphocytes, dendritic cells, and natural killer (NK) cells. Following a respiratory viral infection, these cells are recruited to the respiratory tissue. It seems that zinc can enhance the proliferation of CD8 + cytotoxic T lymphocytes. These cells are crucial in the immune response to respiratory viruses [33, 34]. Zinc deficiency may impair Th1 cell function; impair the production of IL-1, IL-2, IL-4, and IFN- $\gamma$; shift Th1/Th2 balance to Th2; reduce B cell populations; attenuate killing activity of NK cells; and reduce CD8 + T cell population [35-38].

Zinc supplementation may eliminate many of the effects of zinc deficiency on immune cells. It seems that zinc supplementation can increase the numbers of $\mathrm{T}$ lymphocytes in older individuals [39]. Moreover, zinc is engaged in the recognition of MHC I by NK cells, and depletion of $\mathrm{Zn}$ affects the lytic activity of NK cells [40]. Another study has shown that zinc supplementation in individuals with zinc deficiency leads to an increase in ratios of $\mathrm{CD} 4+$ to $\mathrm{CD} 8+$ lymphocytes 


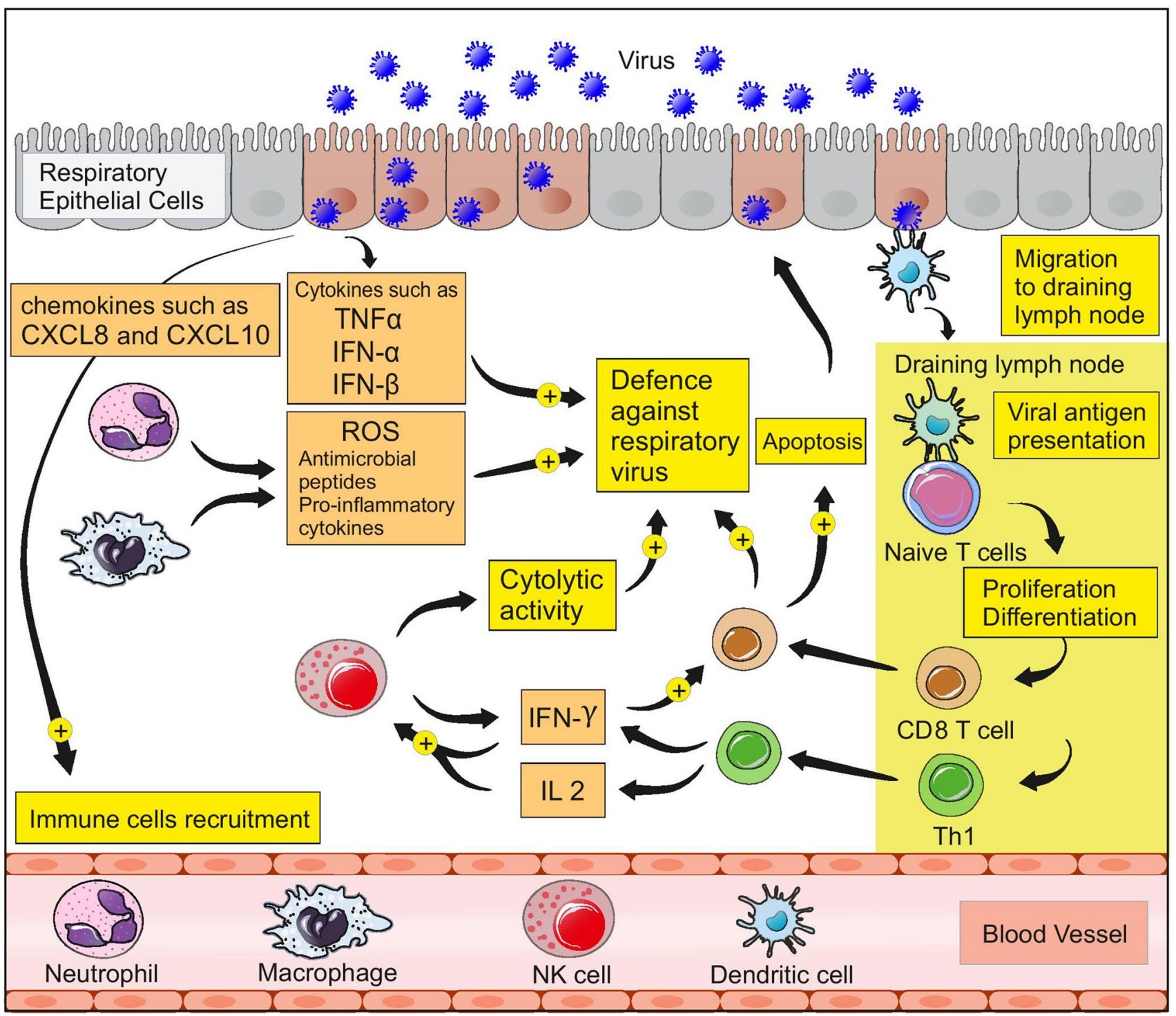

Fig. 1 Anti-viral immune response in the respiratory tract

[41]. Besides, zinc is essential for regulation of the balance between the various $\mathrm{T}$ cell subdivisions $[42,43]$. Experiments in humans demonstrated that decreased zinc content reduces the development of Th1, and thus, the balance between Th 1 and Th2 is disturbed. Th1/Th2 imbalance is eliminated via zinc supplementation [44]. Zinc deficiency reduces the production of antibodies and the number of $\mathrm{B}$ lymphocytes [34]. Zinc may reduce excessive inflammatory response by modulating Treg functions [45]. In Treg development, two zinc-dependent molecules of IRF-1 and TGF$\beta$-induced Smad 2/3 signaling are involved [46]. Zinc supplementation enhanced TGF- $\beta$-induced Smad $2 / 3$ signaling and dampened IRF-1 activity [47]. Zinc deficiency resulted in increased NF- $\mathrm{KB}$ expression in the lungs, leading to upregulation of target genes, including ICAM-1, TNF $\alpha$, and
IL-1 $\beta$ [48]. In addition, it seems that zinc deficiency can lead to enhanced production of pro-inflammatory cytokine (TNF $\alpha$, IL-6, CXC L1), enhanced migration of neutrophils, and increased production of CXC L1 and IL-23 by macrophages, possibly through NF-KB activation [49]. By inhibiting dephosphorylating enzymes, such as protein tyrosine phosphatases (PTP), zinc can directly regulate immune system activity [50]. PTPs can regulate TCR signaling [51]. It seems that inhibiting PTP1B expression may increase the expression of CXCL1, CXCL9, and CXCL10 during RSV infection [52]. Therefore, PTPs may be important during respiratory viral infection. As mentioned in the previous section, interferons (IFNs) are inflammatory stimulus and play a key role in orchestrating adaptive and innate immunity system [52]. In vitro zinc therapy has been shown to increase 
the production of IFN $\alpha$ by white blood cells [53]. It is proposed that zinc may stimulate the up-regulation of anti-viral enzymes including protein kinase RNA-activated (PKR) and latent ribonuclease (RNase L). These enzymes are important in type I IFN anti-viral activity [5, 54]. It seems that high doses of zinc can inhibit IFN- $\gamma$ production and lymphocyte function [44]. Therefore, zinc may also have immunosuppressive effects.

The relationship between Zinc and IFN- $\lambda$ is also interesting. One study showed that zinc with interfering in IFN- $\lambda 3$ binding to IFNL receptor $1 \mathrm{can}$ act as a specific and potent inhibitor of IFN- $\lambda 3$ signaling. Strong zinc-mediated inhibition of IFN- $\lambda 3$-induced CXCL10 expression has also been demonstrated in vitro, indicating the biological complexity of zinc [55]. In addition to these, the intracellular availability of zinc may play an important role in anti-viral activity [56]. Zn transport is principally mediated by two major transporters: (1) the zinc transporter ( $\mathrm{ZnT})$ or solute carrier 30 (SLC30) family and (2) the zinc importer (ZIP), Zrt (zinc-regulated transporter)-like, Irt (iron-regulated transporter)-like proteins, or solute carrier 39A (SLC39A) family [57]. Currently 10 members of the ZnT (ZnT 1-10( family and 14 members of the Zip family (ZIP 1-14) have been identified [58]. ZnT transporters reduce intracellular $\mathrm{Zn} 2+$ by efflux of $\mathrm{Zn} 2+$ from the cytoplasm to outside the cell or influx into cellular organelles, such as lysosome and endoplasmic reticulum (ER). ZIP transporters, which carry out the opposite role, increase intracellular $\mathrm{Zn} 2+$ by influx and import of $\mathrm{Zn} 2+$ into the cytoplasm from outside the cell or cellular organelles [59]. It seems that zinc transporter SLC39A8 (Zip8) is abundantly expressed in the lung [60]. In lung epithelial cells among the ZnT and ZIP transporter genes, only ZIP8 is strongly induced by TNF- $\alpha$. Thus, Zip8 is a critical regulator in zinc-mediated cyto-protection and plays a role in the survival of lung epithelial cells [61]. Besides, Zip8 controls IFN expression by regulating zinc release from lysosomes [62]. It seems that Zip8 expression in human monocytes can also be up-regulated in response to LPS [63]. There seems to be an interesting relationship between the NF-kB signaling pathway, and zinc transporters, especially ZIP8. It seems that NF-kB activity may be regulated by zinc during innate immune response [48]. Studies have shown that zinc plays an important role in regulating the activity of the NF-kB signaling pathway, and this regulation may be cell-specific [64, 65]. It seems that zinc can induce anti-viral response and inhibit dengue virus replication in lung epithelial cells and control viral infection by activation of NF-KB signaling pathway [66]. Besides, ZIP8 is a potent negative feedback regulator of NF-kB. ZIP8 can negatively regulate immune balance by directing zinc into the cytosol, leading to inhibition of IkB kinase (IKKb) [63]. An in vivo study showed that zinc supplementation induced the expression of Zip8 and ameliorated lung injury [67].
IL-23 and CXCL1 production and airway neutrophil infiltration are increased in ZIP8-deficient mice following bacterial infection [68]. ZnT1, ZnT4, and Zip1 transporters are expressed in the lung tissue. ZIP1 and ZIP2 are also present in lung alveolar macrophages and appear to play an important role in the efferocytosis activity of these macrophages $[69,70]$. Paracrine or autocrine signaling in response to type I IFNs (IFN- $\alpha / \beta)$ can lead to up-regulation of a wide array of IFN-stimulated gene (ISG) products which can target viruses life cycle [71]. One of the ISG products is zinc-finger anti-viral protein (ZAP) encoded by the zincfinger CCCH-type, anti-viral 1 (ZC3HAV1) gene. ZAP is a member of the poly (ADP-ribose) polymerase (PARP) family $[71,72]$. One study showed that ZAP and its cofactors TRIM25 and KHNYN are expressed in lung cells. It seems that ZAP can bind to $\mathrm{CpG}$ dinucleotides regions of viral RNA in lung cells [15]. ZAP does not have enzymatic activity and exert preventive effects against viral replication through interaction with TRIM25 and KHNYN [73]. A20 protein is another important zinc-finger protein. This protein is also known as TNF $\alpha$-induced protein 3 (TNFAIP3). A20 is a cytoplasmic protein that is composed of two domains: a C-terminus domain built up by a unique seven zinc-finger structure with ubiquitin-binding activity and an $\mathrm{N}$-terminus ovarian tumor (OTU) domain with deubiquitinase activity [74]. The A20 protein is a negative regulator of TLR, retinoic acid-inducible gene 1 (RIG-I)-mediated signaling, IRF signaling pathway, and NF-KB signaling pathway [75-77]. A20 can effectively regulate NF-kB signaling via affecting a range of related factors including,TNF receptor-associated factor 6 (TRAF6: TRAF pathways), NF-KB essential modulator (NEMO), receptor-interacting protein 1(RIPl), tumor necrosis factor receptor 1 (TNFR1), CD40, toll-like receptors (TLRs), NOD-like receptors (NLRs), and the interleukin-1 receptor (IL-1R) [40, 78]. It seems that inhibition of A20 expression in respiratory epithelium can enhance the protection against influenza infection. In later stages of infection, this improved protection may be associated with suppression of CCL2 expression and modulation of pulmonary cytotoxic T cell [79]. A study on RSV-infected cells showed that down-regulation of A20 can increase apoptosis and induce an innate immune response in infected epithelial cells [80]. Zinc exerts an inhibitory effect on the activation of NF-kB by inducing the A20. It seems that A20 can inhibit NF-kB, possibly through inactivation of TRAF6 [81, 82]. Therefore, it seems that zinc can decrease the production of pro-inflammatory cytokines such as IL- $1 \beta$, and TNF- $\alpha$ via up-regulation of A20 leading to attenuation of NF-kB [32]. It has been suggested that zinc supplements may affect NF-kB activity by altering A20 activity [83].

The zinc-dependent metallopeptidase STE24 (ZMPSTE24) is another zinc-dependent protein that can act as a broad-spectrum anti-viral protein. This protein is an essential 
inhibitor of viral entry and can restrict wide range of viruses including influenza and Ebola [50, 84]. Increased viral load was reported in the lungs of ZMP STE24-deficient mice following influenza infection [85]. ZMPSTE24 expression is necessary for interferon-induced transmembrane protein (IFITM) activity. This protein can prevent viral entry [84, 85]. Autophagy likely acts as both an anti-viral and pro-viral pathway in the pathogenesis and life cycles of a wide range of viruses [86]. Increasing evidence indicates the idea that in the autophagy process zinc may be a positive regulator [87-89]. However, it seems that more studies are needed in this regard. All of the above events depend on zinc presence in the body, so zinc deficiency may cause a significant disruption in anti-viral defense and immune regulation in the respiratory system. Table 1 summarizes the most important events mentioned above.

\section{Zinc and Respiratory Viruses}

As mentioned above, zinc is a crucial trace element for antiviral defense and immune regulation in the respiratory tract. Influenza, RSV, and SARS-COV2 are among the viruses that can cause severe respiratory infections and even be lifethreatening. Several studies have investigated the importance of zinc in these viral infections, and in this section, we will review the findings of these interesting studies. Figure 2 also summarizes the most important points mentioned in this section.

\section{Zinc and Influenza Virus Infection}

The influenza virus is a known main factor of acute respiratory disease, which is extremely contagious and transmitted from person to person via respiratory droplets. Airway epithelial cells are the main target of the virus for attack and replication. Influenza virus can cause seasonal respiratory infection and associated pandemic [90, 91]. The flu pandemic has occurred many times. The H2N2 (1957), the H3N2 (1967), the H1N1 (2009), and the H1N1 (1918) pandemics are among the most important of flu pandemics. The pandemic of the influenza virus, which happened in 1918, was terrible, and 40-50 million peoples have been died [92]. Based on various nuclear proteins (NP) and matrix proteins (M), there are four groups of influenza viruses (A, B, C, D). A and B types of influenza virus are the main causes of influenza infection in humans [93]. Influenza viruses belong to the Orthomyxoviridae family. The virus consists of one chain negative-sense RNA genome that includes eight-segmented in A and B type [94, 95]. Binding each of the vRNA fragments to heterotrimeric polymerase complex is required for ribonucleoproteins (RNP) formation [96]. Because the influenza virus replicates in the host cell nucleus, RNP must be transported to the nucleus. In this process, there is interaction between the RNP and cellular transport systems [97]. Hemagglutinin (HA) and neuraminidase (NA) are important glycoproteins. These proteins are presented on the external surface of the virus [98]. Influenza viruses are divided into different subtypes based on HA and neuraminidase NA [99]. H1N1 and H3N2 are among the most important of these subtypes in influenza A and are considered as the main causes of seasonal influenza [100].

HA has a key role in virus entry into the host cell and primary phase infection. When the globular head of HA adjoins to the sialic acid receptor in the respiratory tract epithelial cell, the replication cycle of the influenza virus can start $[101,102]$. After this step, clathrin-mediated endocytosis has occurred, and then, the endosome is formed [103]. The combination of virus and endosome membrane is facilitated by acidic conditions in the late endosome, which leads to structural change in HA and starts a progression of events

Table 1 Zinc functions in anti-viral immune response in the respiratory system

\begin{tabular}{|c|c|c|}
\hline Target & Function & Outcomes \\
\hline Respiratory epithelial barrier & Attenuation of apoptosis and para-cellular leakage & $\begin{array}{l}\text { Maintaining the structure and function of the respiratory } \\
\text { epithelium barrier } \\
\text { Help to host defense }\end{array}$ \\
\hline Immune cells & $\begin{array}{l}\text { Increasing the numbers of T lymphocyte } \\
\text { Enhancement of NK cells killer activity } \\
\text { Regulation of Th1/Th2 balance } \\
\text { Modulation of Treg functions } \\
\text { Increasing the production of IFN } \alpha \text { by leukocytes }\end{array}$ & $\begin{array}{l}\text { Enhancement and regulation of immune response to respira- } \\
\text { tory viruses }\end{array}$ \\
\hline Zip8 & Induction of Zip8 expression & Amelioration of lung injury \\
\hline ZAP & Zinc is present in zinc-finger motif & Attenuation of viral replication \\
\hline A20 protein & Zinc is present in zinc-finger motif & $\begin{array}{l}\text { Decreasing production of pro-inflammatory cytokines such as } \\
\text { IL- } 1 \beta, \text { IL- } 8 \text { and TNF- } \alpha \\
\text { Attenuation NF-kB activation }\end{array}$ \\
\hline $\begin{array}{l}\text { Zn-dependent metallopepti- } \\
\text { dase STE24 (ZMPSTE24) }\end{array}$ & Zinc is present in the active site of the enzyme & $\begin{array}{l}\text { Inhibition of viral entry } \\
\text { Restriction of enveloped RNA and DNA viruses }\end{array}$ \\
\hline
\end{tabular}


Fig. 2 Anti-viral activities of zinc in respiratory viral infections

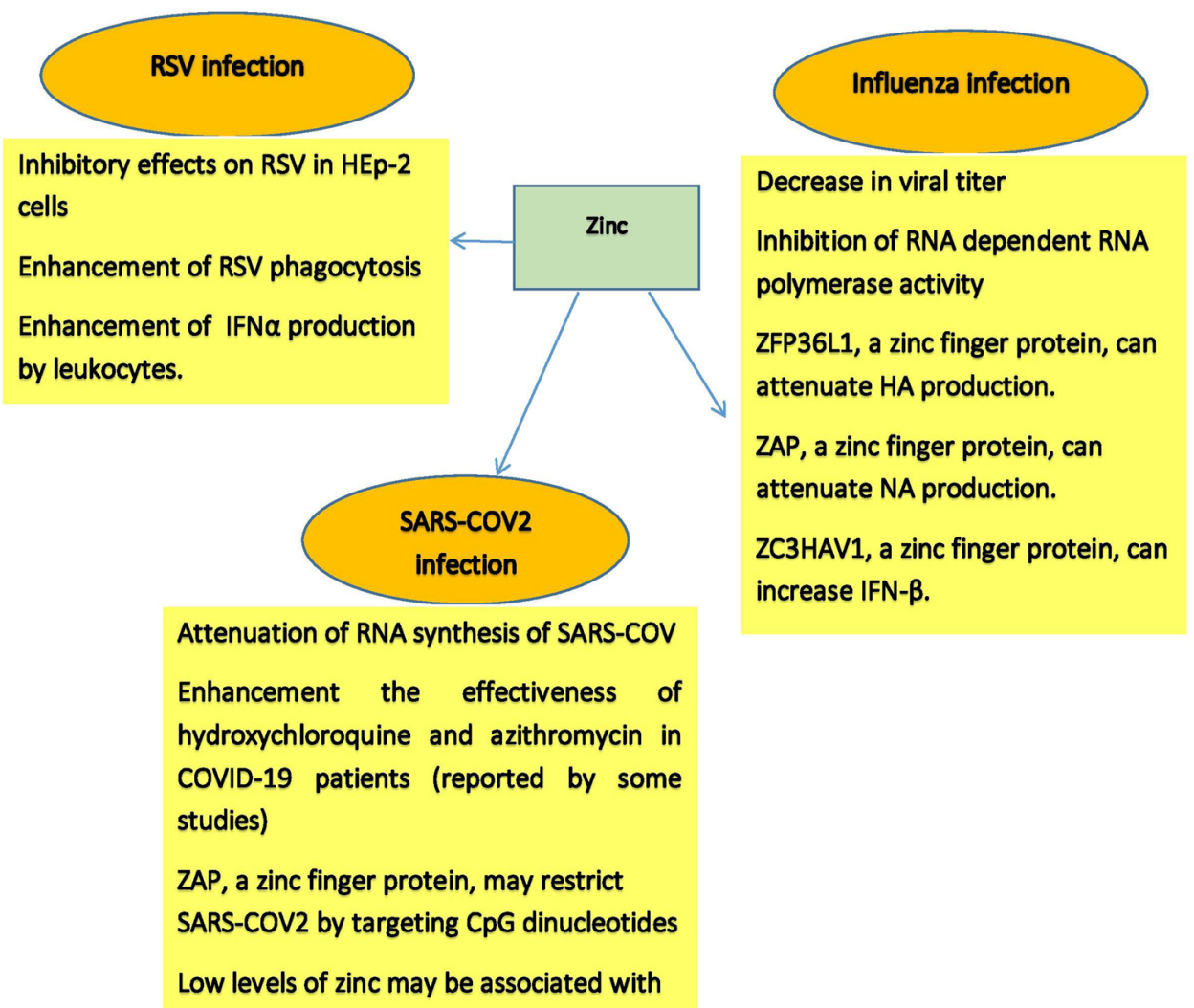

that can cause viral ribonucleoprotein (vRNP) releasing into the cytoplasm. Finally, vRNA goes into the nucleus [96, 104-106]. After entering the viral ribonucleoprotein into the nucleus, RNA-dependent RNA polymerase, which is part of vRNP, uses negative-sense viral RNA as a template to make two types of positive-sense RNAs [95, 105]. One of these RNAs is viral mRNAs, which encode viral proteins, and the other is complementary RNA, which is transcribed into negative-sense viral RNA. Negative-sense viral RNAs are assembled with viral proteins and form viral particles. Viral particles are released through budding. HA and NA play a key role in viral particle releasing [95, 107, 108]. The primary anti-viral reaction against influenza can lead to the secretion of and type I IFNs and pro-inflammatory cytokines such as TNF- $\alpha$ and IL-6 [109, 110]. Immune cells are recruited to the site of infection to control the spread of the virus. Excessive and uncontrolled production of a proinflammatory cytokine called "cytokine storm" can cause tissue damage and organ failure [111, 112]. Due to mutations that may occur during replication in the virus genome, mutant virus can be produced, leading to the virus becoming resistant to existing antibodies and escape from neutralization $[113,114]$. Therefore, recognizing alternative anti-influenza factors with various mechanisms is of importance. Due to zinc's role in anti-viral defense and immune regulation, several studies have investigated the importance of zinc in influenza infection. The findings of an interesting study showed that zinc oxide nanoparticles have an anti-viral effect only after a viral infection of the cells, which finally leads to a decrease in viral titer [115]. Zinc appears to be able to inhibit influenza virus' RNA polymerase activity [116]. A recent study showed that zinc-finger protein ZFP36L1 has anti-viral properties and can enhance host anti-viral defense against influenza A virus by attenuating the production of viral proteins including HA, M, and NS [117]. In the previous section, we discussed the importance of zinc-finger anti-viral protein (ZAP). One study showed that the short isoform of this protein (ZAPS) could inhibit the expression of influenza viral proteins including PA, PB2, and NA [14].

SOD1 is a crucial zinc-dependent antioxidant enzyme. It appears that this enzyme can significantly attenuate viral polymerase activity and has anti-viral properties against H1N1IAV infection. It seems that repression of the copperzinc SOD1 enzyme by the IAV may facilitate virus replication by disrupting cell redox balance [118]. As mentioned in the previous section, ZMPSTE24 is also an important zinc-dependent protein involved in anti-viral defense and immune regulation. One study showed that IAV-infected ZMPSTE24-deficient mice had increased viral burden, cytokine production, and mortality, indicating an important role for this zinc-dependent protein in anti-viral defense, and immune regulation following IAV infection [85]. Zinc-finger 
CCCH-type anti-viral protein 1 (ZC3HAV1) is another zincdependent protein involved in the anti-viral defense of host cells. One study showed that this protein could attenuate IAV replication by increasing IFN- $\beta$ expression [119]. All the results summarized above indicate the importance of zinc in the defense against influenza infection. These findings partly justify the results of clinical studies regarding the usefulness of zinc in the prevention and treatment of influenza infection.

\section{Zinc and Respiratory Syncytial Virus Infection}

Respiratory syncytial virus (RSV) is one of the most important causes of hospitalization for respiratory system infection in young children $[120,121]$. RSV is a negative-sense, single-stranded RNA virus and is consisted of 11 proteins that are encoded by a $15.2 \mathrm{~kb}$ RSV genome. Nucleoprotein $(\mathrm{N})$, small hydrophobic protein $(\mathrm{SH})$, matrix protein $(\mathrm{M})$, phosphoprotein $(\mathrm{P})$, attachment glycoprotein $(\mathrm{G})$, fusion protein (F), M2-1, M2-2, large protein (L), and non-structural proteins (NS1 and NS2) are RSV proteins [122, 123]. Among these, $\mathrm{G}$ and $\mathrm{F}$ proteins are responsible for the infection of host cells [124]. The virus genome also consists of 10 genes. RSV has a lipid envelope that encompasses the ribonucleocapsid [125, 126]. RSV infection can cause serious problems in the respiratory system. It seems that after 2 to 8 days of RSV incubation, the virus is replicated in the nasopharyngeal epithelium [121, 123]. Some symptoms including fever, nasal congestion, and rhinorrhea are correlated with RSV infection in early days [120]. The inflammation that is resulting from RSV infection is characterized by necrosis of the small airway epithelium and increasing of the mucus secretion, which causes flow in the small airways. The subsequent clinical discoveries have shown bronchiolitis signs such as excessive inflation, atelectasis, and wheezing. It seems that Th2 cells and their cytokines, Th1 cells, and cytotoxic T cells are important in the immune response to RSV infection; furthermore, releasing some leukotrienes by $\mathrm{T}$ cells and eosinophils is seen. Also, in RSV infection, the levels of IgE antibody and IL-33 are elevated [121, 127-130]. IL-33 is involved in type 2 immunity and mucin production in the lung epithelial cells [131, 132]. Despite some decades of attempts, there is no approved vaccine for preventing RSV infection until yet [133]. Ribavirin is an expensive anti-viral drug approved for the treatment of RSV infections. Some of the most important and supportive treatments for RSV infection are oxygen therapy and using of mechanical ventilation for the patients [134]. Many studies have mentioned the role of micronutrients such as zinc in the treatment of various diseases, including viral infections $[135,136]$. As mentioned in previous sections, zinc has many essential roles in the immune system, including regulation of proliferation, differentiation, and maturation of Immune cells. Zinc is involved in the regulation of leukocytes and lymphocytes activities and modulation of inflammatory responses. It seems that zinc deficiency, which is defined as insufficient zinc for body needs, results in attenuation of immune system [5, 7].

Although very few studies have been conducted on the importance of zinc and zinc-containing proteins in RSV infection, the findings indicate that zinc is helpful in controlling RSV infection. It seems that blood zinc level in children with RSV pneumonia is significantly low [5, 137]. In one exam, the inhibitory effects of zinc on RSV infection were seen, when incubated with human epithelial type 2 (HEp-2) cells only before infection [138]. Studies also have shown that zinc treatment enhances interferon $\alpha$ (IFN $\alpha$ ) production by leukocytes. IFN $\alpha$, an immune-stimulatory cytokine, has anti-viral activity. Increasing the expression of antiviral genes by IFN $\alpha$ that are correlated with degradation of viral RNA as well as inhibition of viral RNA translation is proposed to be stimulated by zinc [5, 7]. The studies also reported that intake of at least $75 \mathrm{mg}$ zinc per day could decrease the duration of pneumonia symptoms [139]. Therefore, it is necessary to study the relationship between zinc supplementation and RSV-induced pneumonia. One study showed that fetal ethanol exposure could be associated with immunosuppression and reduced RSV phagocytosis. However, maternal zinc supplements could enhance RSV phagocytosis and reduce RSV burden in the lungs [140], indicating the importance of sufficient zinc levels in the neonatal immune system. Undoubtedly, further studies could reveal more dimensions of the benefits of zinc in controlling RSV infection. Studying the role of zinc-dependent anti-viral proteins in RSV infection can be very helpful and should be considered in future studies.

\section{Zinc and SARS-COV2 Infection}

Coronavirus disease 2019 (COVID-19) was reported in late 2019 in Wuhan, China. COVOD-19 is caused by severe acute respiratory syndrome coronavirus 2 (SARS-CoV-2), an RNA virus from the coronaviruses family. Although some coronaviruses cause mild symptoms such as colds, others, including SARS, MERS, and COVID-19, cause severe respiratory symptoms that can be life-threatening. Some studies have shown a significant similarity between SARS-COV2 and the SARS-COV in terms of gene sequencing, with about $79.7 \%$ similarity being reported [141]. The SARAS-COV2 genome encodes four important proteins named $\mathrm{S}$ (spike), $\mathrm{E}$ (envelope), $\mathrm{M}$ (membrane), and $\mathrm{N}$ (nucleocapsid). S, E, and $\mathrm{M}$ appear to be associated with the envelope structure of the virus, and $\mathrm{N}$ is involved in the maintenance of the virus genome [142]. S appears to play a pivotal role in the virus entry to the respiratory tract epithelial cell by binding to ACE2 receptors [143]. Once the virus genome enters the host cell, replication, transcription, and translation occur, 
and after assembly, infectious viral particles are released from the cell through budding. Detection of virus RNA by innate immune system receptors initiates an immune response to the virus. Following this identification, a wide range of cytokines and chemokines against the virus are produced. IL-1 $\beta$, IL6, TNF $\alpha$, CXCL8, and MCP1 are among these cytokines and chemokines [144]. Lung epithelial cells, alveolar macrophages, and dendritic cells produce significant amounts of these cytokines and chemokines. The JAK-STAT and NFKB signaling pathways play a very important role in the production of above-mentioned proinflammatory cytokines [145]. Given that the IFN response in SARS infection is significantly attenuated, it has been hypothesized that SARS-COV may be able to escape the innate immune barrier by attenuating or delaying the IFN response [144]. Therefore, this issue should be studied in SARS-COV2 infection precisely. Adaptive immune response in COVID-19 also starts by delivering antigens to CD4+ and CD8+ T cells [145]. There have been reports of decreased T lymphocyte and NK cell counts in patients with COVID19 [146]. Although the production of the pro-inflammatory cytokines mentioned above is very important for defense against SARS-COV2, their uncontrolled and excessive production, called cytokine storms, can be very dangerous and lead to lung damage and ARDS. Therefore, it seems that regulating immunity and preventing excessive inflammation are very important in SARS-COV2 infection.

Due to the importance of zinc in anti-viral defense and immune regulation in the respiratory tract mentioned in the previous sections, after the COVID-19 pandemic, more attention was paid to this vital trace element. Although not many studies have been done so far, some published results are interesting. It seems that zinc can attenuate the RNA synthesis of SARS-COV and have an inhibitory effect on replicating this virus [13]. Besides, one study showed that zinc could inhibit papain-like protease 2 (PLP2) of SAPSCOV [147]. This enzyme is very important in virus virulence. Since there are many similarities between the SARSCOV and SARS-COV2 genomes, it is necessary to study the above-mentioned results inSARS-COV2 infection carefully. Clinical studies in patients with COVID-19 have also reported interesting results. One study showed that serum zinc levels in patients with COVID-19 were significantly lower than in the healthy control group. In addition, the findings of this study showed that ARDS rate, length of hospital stay, and mortality increased in COVID-19 patients with zinc deficiency [148]. A study of pregnant women with COVID19 showed that serum zinc levels in these patients were significantly reduced compared to the control group. Besides, an inverse correlation was reported between serum zinc and IL6 levels. There also appears to be an inverse correlation between zinc/copper ratio and disease severity in pregnant women with COVID-19 [149]. Another study showed that normal levels of zinc and selenoprotein $\mathrm{P}$ were associated with higher survival in patients with COVID-19 [150]. The results of some studies have shown that zinc can be effective in the treatment of COVID-19 and increase the effectiveness of drugs such as hydroxychloroquine and azithromycin. One study of 3473 patients with COVID-19 showed that a combination of zinc and ionophore hydroxychloroquine could reduce the in-hospital mortality rate by $24 \%$; in contrast, zinc alone or ionophore alone could not reduce mortality [151]. One study showed that zinc sulfate, along with hydroxychloroquine and azithromycin, could reduce ICU admission, need for ventilation, and mortality in hospitalized patients with COVID-19 [152]. Another study of outpatients with COVID-19 showed that treatment of these patients with low-dose hydroxychloroquine and azithromycin combined with zinc could reduce hospitalization rates and mortality rates [153]. These promising clinical observations are justified by the role of zinc in anti-viral defense and immune regulation in the respiratory tract. However, another study showed that zinc sulfate did not have a significant effect on reducing in-hospital mortality in patients with COVID-19 [154].

In addition, one study also showed that zinc supplementation did not have a significant effect on the effectiveness of hydroxychloroquine in the treatment of COVID-19, and the use of zinc supplementation with this drug did not cause a significant difference in parameters such as clinical recovery, need for mechanical ventilation, and mortality rates [155]. Therefore, more studies should be done in this field. It has recently been shown that the combination of nitazoxanide, ribavirin, ivermectin, and zinc supplementation has a significant effect on clearing the SARS-COV2 [156]. A limited number of studies have been performed on the importance of anti-viral zinc-dependent proteins in SARS-COV2 infection. One study showed that zinc-finger anti-viral protein (ZAP) could restrict SARS-COV2 by targeting $\mathrm{CpG}$ dinucleotides in the virus genome [15]. Therefore, further studies on the importance of ZAP and other zinc-dependent proteins mentioned in the previous section in COVID-19 are necessary.

\section{Zinc and Acute Respiratory Distress Syndrome (ARDS)}

ARDS, which develops as a result of widespread inflammation in the lungs, can lead to severe respiratory failure and death. The most important clinical symptoms of ARDS are tachypnea and dyspnea, which can cause annoying and dangerous conditions. Respiratory viral infections mentioned above can lead to ARDS. Due to the importance of zinc in regulating immunity in the respiratory tract, a limited number of studies have investigated the relationship between zinc and ARDS. In one of these studies, it was shown that low serum zinc levels are very frequent at the onset of 
acute failure of the respiratory system [157]. Another study showed that plasma zinc levels in patients with ARDS were significantly lower than in healthy individuals [158]. One study showed that zinc consumption in boys with acute lower respiratory infection could reduce the duration of fever and severe disease status [159]. Another study of children hospitalized with pneumonia also showed that zinc could significantly reduce the time of tachypnea and fever [160]. Besides, zinc salicylate seems to have beneficial effects in preventing airway wall remodeling [161]. A study of 269 patients with COVID-19 showed that low levels of zinc were associated with severe ARDS (OR, 15.4; 95\% CI, 6.5-36.3; $\mathrm{P}<0.001$ ) [162]. Zinc deficiency appears to be associated with ventilator-induced lung injury [158]. Therefore, zinc supplements may be helpful in preventing ventilator-induced lung injury in patients who require mechanical ventilation, which should be studied in the future. In addition to these, A20, a zinc-dependent protein, appears to play a role in alleviating ARDS, possibly due to its role in inhibiting TNF- $\alpha$ and NF- $\mathrm{KB}$ p65 and enhancing IL10 production [163]. All of these above-mentioned promising results suggest that adequate zinc levels may play a protective role against ARDS. Therefore, more studies are needed in this area. It is possible that sufficient levels of zinc in patients with respiratory viral infections can reduce the severity of the disease and prevent ARDS and severe respiratory conditions. Undoubtedly, future studies will provide more information in this regard.

\section{Zinc and Vaccination Against Respiratory Viruses: Can It Be Helpful?}

Undoubtedly, vaccination is one of the most effective ways to prevent infectious diseases, especially respiratory viral infections. Vaccination against the influenza virus plays an important role in preventing seasonal influenza, but an effective vaccine against RSV has not yet been approved. Several vaccines have also been developed against COVID-19 that will undoubtedly play a key role in controlling the COVID-19 pandemic. However, finding ways to increase the effectiveness of vaccines and boost the immune response following vaccination has always been considered as an important area of research. Some studies have examined the efficacy of zinc in enhancing the effectiveness of respiratory virus vaccines. The majority of studies focusing on the flu vaccine have reported conflicting findings, and it is not yet clear whether zinc can increase vaccine efficacy. A study in pigs showed that zinc oxide might help boost humoral immune responses following vaccination against swine influenza viruses. In this study, it was revealed that high doses of zinc (2500 ppm) in combination with the vaccine could significantly increase hemagglutination inhibition titers (HAI) following influenza infection [164]. Another study of 9- to 18-year-old heart disease patients found that supplementing with zinc along with the influenza vaccine could reduce the incidence of malaise, a common adverse effect of the influenza vaccine. Besides, this study showed that zinc supplementation along with influenza vaccine could significantly reduce serum levels of TNF $\alpha$ in these children [165]. However, studies on the elderly have shown that zinc supplementation does not significantly affect the effectiveness of the influenza vaccine. In one of these studies, which was performed on 384 people with a mean age of 82 years, it was shown that zinc supplementation had no significant effect on antibody titers against influenza antigens after vaccination and also had no effect on the number of CD4 + and CD8 + lymphocytes [166]. Another study of 60 healthy people aged 64 to 90 years found that zinc supplementation did not affect the immune response following influenza vaccination [167]. Serum zinc levels do not appear to have a significant effect on the immune response following influenza vaccination. An interesting study of 205 patients over 65 years showed that there was no significant association between serum zinc levels and HAI after influenza vaccination, indicating that serum zinc levels had no significant effect on the immune response following influenza vaccination [168]. However, these studies have been performed on elderly groups, and more studies are needed on other age groups.

One study also showed that injectable supplement of zinc, manganese, selenium, and copper might enhance peripheral blood mononuclear cell proliferation and IFN- $\gamma$ production in response to bovine respiratory syncytial virus (BRSV) stimulation following vaccination in dairy calves [169]. These interesting findings can be considered in the design of future studies. Because a very short time has passed since the vaccination against COVID-19, the effect of zinc on the effectiveness of these vaccines is still unknown. However, increasing the efficacy of these vaccines, especially against SARS-COV2 mutant species, could become an active research area. Considering the importance of zinc in antiviral defense and immune regulation and its positive effect on the efficacy of some drugs in the treatment of COVID-19 mentioned above, the effect of zinc supplementation on the effectiveness of COVID-19 vaccines can be studied. In addition, the relationship between zinc deficiency and the side effects of COVID-19 vaccines can be studied, as well. Overall, more studies are needed to make accurate conclusions about the effect of zinc on the effectiveness of vaccination against respiratory viruses.

\section{Conclusion and Future Direction}

Zinc, an essential trace element, affects the anti-viral immune response and immune regulation in the respiratory tract. Many of the critical proteins involved in anti-viral defense contain zinc in their structure. Interesting clinical 
findings have been presented that indicate the importance of adequate zinc levels in preventing respiratory viral infections. It seems that zinc can disrupt the replication and infectivity of some respiratory viruses. Some studies performed during the COVID-19 pandemic have suggested that zinc may increase the effectiveness of some of the drugs recommended for the treatment of COVID-19. Some reports suggest that zinc has a positive effect on preventing ARDS and lung damage following mechanical ventilation. The link between zinc and the effectiveness of respiratory virus vaccines is still unclear, and the published findings are somewhat contradictory. Therefore, more studies are needed in this regard. These studies could focus specifically on COVID-19 vaccines. Investigation of the association between zinc levels and side effects of COVID-19 vaccines could be another interesting area for future studies. In general, due to the relatively high prevalence of zinc deficiency, it is necessary to pay more attention to this trace element. The number of studies examining the importance of zinc in respiratory infections is relatively low, and it is required to direct future studies to zinc and other trace elements.

Acknowledgements We would like to express our gratitude to department of Clinical Biochemistry and Laboratory Medicine of Tabriz University of Medical Sciences

\section{Declarations}

Ethical approval Not applicable.

Consent for Publication Not applicable.

Conflict of interest The authors declare no conflict of interest.

\section{References}

1. Moriyama M, Hugentobler WJ, Iwasaki A (2020) Seasonality of respiratory viral infections. Annual Rev Virol 7:83-101. https:// doi.org/10.1146/annurev-virology-012420-022445

2. Wang X, Li Y, O'Brien KL, Madhi SA, Widdowson MA, Byass $P$ et al (2020) Global burden of respiratory infections associated with seasonal influenza in children under 5 years in 2018: a systematic review and modelling study. Lancet Glob Health 8:e497-e510. https://doi.org/10.1016/s2214-109x(19)30545-5

3. Shi T, McAllister DA, O'Brien KL, Simoes EAF, Madhi SA, Gessner BD et al (2017) Global, regional, and national disease burden estimates of acute lower respiratory infections due to respiratory syncytial virus in young children in 2015: a systematic review and modelling study. Lancet (London, England) 390(10098):946-958. https://doi.org/10.1016/s0140-6736(17) 30938-8

4. Shi T, Denouel A, Tietjen AK, Campbell I, Moran E, Li X, Campbell H, Demont C, Nyawanda BO, Chu HY, Stoszek SK, Krishnan A, Openshaw P, Falsey AR, Nair H (2020) Global disease burden estimates of respiratory syncytial virus-associated acute respiratory infection in older adults in 2015: a systematic review and meta-analysis. J Infect Dis 222(7):S577-S583. https:// doi.org/10.1093/infdis/jiz059

5. Skalny AV, Rink L, Ajsuvakova OP, Aschner M, Gritsenko VA, Alekseenko SI, Svistunov AA, Petrakis D, Spandidos DA, Aaseth J, Tsatsakis A, Tinkov AA (2020) Zinc and respiratory tract infections: perspectives for COVID-19 (Review). Int J Mol Med 46:17-26. https://doi.org/10.3892/ijmm.2020.4575

6. Vaghari-Tabari M, Jafari-Gharabaghlou D, Sadeghsoltani F, Hassanpour P, Qujeq D, Rashtchizadeh N, Ghorbanihaghjo A (2020) Zinc and selenium in inflammatory bowel disease: trace elements with key roles? Biol Trace Elem Res. https://doi.org/10.1007/ s12011-020-02444-w

7. Read SA, Obeid S, Ahlenstiel C, Ahlenstiel G (2019) The role of zinc in antiviral immunity. Adv Nutri (Bethesda, Md) 10:696710. https://doi.org/10.1093/advances/nmz013

8. Mao S, Zhang A, Huang S (2014) Meta-analysis of $\mathrm{Zn}, \mathrm{Cu}$ and Fe in the hair of Chinese children with recurrent respiratory tract infection. Scand J Clin Lab Invest 74:561-567. https://doi.org/ 10.3109/00365513.2014.921323

9. Lassi ZS, Moin A, Bhutta ZA (2016) Zinc supplementation for the prevention of pneumonia in children aged 2 months to 59 months. Cochrane Database Syst Rev 12:CD05978. https://doi. org/10.1002/14651858.CD005978.pub3

10. Wang L, Song Y (2018) Efficacy of zinc given as an adjunct to the treatment of severe pneumonia: a meta-analysis of randomized, double-blind and placebo-controlled trials. Clin Respir J 12:857-864. https://doi.org/10.1111/crj.12646

11. Science M, Johnstone J, Roth DE, Guyatt G, Loeb M (2012) Zinc for the treatment of the common cold: a systematic review and meta-analysis of randomized controlled trials. Can Med Assoc J 184:E551-561. https://doi.org/10.1503/cmaj.111990

12. Hemilä H (2017) Zinc lozenges and the common cold: a metaanalysis comparing zinc acetate and zinc gluconate, and the role of zinc dosage. JRSM open 8:2054270417694291. https://doi. org/10.1177/2054270417694291

13. te Velthuis AJ, van den Worm SH, Sims AC, Baric RS, Snijder EJ, van Hemert MJ (2010) Zn(2+) inhibits coronavirus and arterivirus RNA polymerase activity in vitro and zinc ionophores block the replication of these viruses in cell culture. PLoS Pathog 6:e1001176. https://doi.org/10.1371/journal.ppat.1001176

14. Tang Q, Wang X, Gao G (2017) The short form of the zinc finger antiviral protein inhibits influenza a virus protein expression and is antagonized by the virus-encoded NS1. J Virol. https://doi.org/ 10.1128/jvi.01909-16

15. Nchioua R, Kmiec D, Müller JA, Conzelmann C, Groß R, Swanson CM, Neil SJD, Stenger S, Sauter D, Münch J, Sparrer KMJ, Kirchhoff F (2020) SARS-CoV-2 Is restricted by zinc finger antiviral protein despite preadaptation to the low-CPG environment in humans. MBio. https://doi.org/10.1128/mBio.01930-20

16. Vareille M, Kieninger E, Edwards MR, Regamey N (2011) The airway epithelium: soldier in the fight against respiratory viruses. Clin Microbiol Rev 24:210-229. https://doi.org/10.1128/cmr. 00014-10

17. Makris S, Paulsen M, Johansson C (2017) Type I interferons as regulators of lung inflammation. Front Immunol 8:259. https:// doi.org/10.3389/fimmu.2017.00259

18. Greiller CL, Martineau AR (2015) Modulation of the immune response to respiratory viruses by vitamin D. Nutrients 7:4240 4270. https://doi.org/10.3390/nu7064240

19. Newton AH, Cardani A, Braciale TJ (2016) The host immune response in respiratory virus infection: balancing virus clearance and immunopathology. Seminars in immunopathology 38:471-482. https://doi.org/10.1007/s00281-016-0558-0

20. Abboud G, Tahiliani V, Desai P, Varkoly K, Driver J, Hutchinson TE, Salek-Ardakani S (2016) Natural killer cells and innate interferon gamma participate in the host defense against respiratory 
vaccinia virus infection. J Virol 90:129-141. https://doi.org/10. 1128/jvi.01894-15

21. Braciale TJ, Sun J, Kim TS (2012) Regulating the adaptive immune response to respiratory virus infection. Nat Rev Immunol 12:295-305. https://doi.org/10.1038/nri3166

22. Honda K, Sakaguchi S, Nakajima C, Watanabe A, Yanai H, Matsumoto M, Ohteki T, Kaisho T, Takaoka A, Akira S, Seya T, Taniguchi T (2003) Selective contribution of IFN-alpha/beta signaling to the maturation of dendritic cells induced by double-stranded RNA or viral infection. Proc Natl Acad Sci USA 100:10872-10877. https://doi.org/10.1073/pnas.1934678100

23. Allie SR, Randall TD (2017) Pulmonary immunity to viruses. Clin Sci (Lond) 1979131:1737-1762. https://doi.org/10.1042/ cs20160259

24. Frank K, Paust S (2020) Dynamic natural killer cell and T cell responses to influenza infection. Front Cell Infect Microbiol 10:425. https://doi.org/10.3389/fcimb.2020.00425

25. Mohammadzadeh I, Qujeq D, Yousefi T, Ferns GA, Maniati M, Vaghari-Tabari M (2020) CRISPR/Cas9 gene editing: a new therapeutic approach in the treatment of infection and autoimmunity. IUBMB Life 72:1603-1621. https://doi.org/10.1002/iub.2296

26. Ragab D, Salah Eldin H, Taeimah M, Khattab R, Salem R (2020) The COVID-19 cytokine storm; what we know so far. Front Immunol 11:1446. https://doi.org/10.3389/fimmu.2020.01446

27. Roohani N, Hurrell R, Kelishadi R, Schulin R (2013) Zinc and its importance for human health: an integrative review. J Res Med Sci 18:144-157

28. Gammoh NZ, Rink L (2017) Zinc in infection and inflammation. Nutrients. https://doi.org/10.3390/nu9060624

29. Roscioli E, Jersmann HP, Lester S, Badiei A, Fon A, Zalewski $P$, Hodge $S$ (2017) Zinc deficiency as a codeterminant for airway epithelial barrier dysfunction in an ex vivo model of COPD. Int J Chron Obstruct Pulmon Dis 12:3503-3510. https://doi.org/10. 2147/copd.s149589

30. Bao S, Knoell DL (2006) Zinc modulates cytokine-induced lung epithelial cell barrier permeability. Am J Physiol Lung Cell Mol Physiol 291:L1132-1141. https://doi.org/10.1152/ajplung.00207. 2006

31. Duerr CU, Fritz JH (2020) Editorial: Immunoregulatory mechanisms of interferon. Front Immunol 11:187. https://doi.org/10. 3389/fimmu.2020.00187

32. Prasad AS (2008) Zinc in human health: effect of zinc on immune cells. Molecular medicine (Cambridge, Mass) 14:353-357. https://doi.org/10.2119/2008-00033.Prasad

33. Hasan R, Rink L, Haase H (2013) Zinc signals in neutrophil granulocytes are required for the formation of neutrophil extracellular traps. Innate Immun 19:253-264. https://doi.org/10.1177/17534 25912458815

34. Hasan R, Rink L, Haase H (2016) Chelation of free Zn2+ impairs chemotaxis, phagocytosis, oxidative burst, degranulation, and cytokine production by neutrophil granulocytes. Biol Trace Elem Res 171:79-88. https://doi.org/10.1007/s12011-015-0515-0

35. Hojyo S, Fukada $T$ (2016) Roles of zinc signaling in the immune system. J Immunol Res 2016:6762343. https://doi.org/10.1155/ 2016/6762343

36. Prasad AS (2000) Effects of zinc deficiency on Th1 and Th2 cytokine shifts. J Infect Dis 182(1):S62-68. https://doi.org/10. 1086/315916

37. Rolles B, Maywald M, Rink L (2018) Influence of zinc deficiency and supplementation on NK cell cytotoxicity. J Funct Foods 48:322-328. https://doi.org/10.1016/j.jff.2018.07.027

38. Kido T, Ishiwata K, Suka M, Yanagisawa H (2019) Inflammatory response under zinc deficiency is exacerbated by dysfunction of the Thelper type 2 lymphocyte-M2 macrophage pathway. Immunology 156:356-372. https://doi.org/10.1111/imm.13033
39. Barnett JB, Dao MC, Hamer DH, Kandel R, Brandeis G, Wu D, Dallal GE, Jacques PF, Schreiber R, Kong E, Meydani SN (2016) Effect of zinc supplementation on serum zinc concentration and $\mathrm{T}$ cell proliferation in nursing home elderly: a randomized, double-blind, placebo-controlled trial. Am J Clin Nutr 103:942-951. https://doi.org/10.3945/ajen.115.115188

40. Jarosz M, Olbert M, Wyszogrodzka G, Młyniec K, Librowski T (2017) Antioxidant and anti-inflammatory effects of zinc. ZincDependent NF-кB Signal Inflammopharmacol 25:11-24. https:// doi.org/10.1007/s10787-017-0309-4

41. Sandstead HH, Prasad AS, Penland JG, Beck FW, Kaplan J, Egger NG, Alcock NW, Carroll RM, Ramanujam VM, Dayal HH, Rocco CD, Plotkin RA, Zavaleta AN (2008) Zinc deficiency in Mexican American children: influence of zinc and other micronutrients on T cells, cytokines, and antiinflammatory plasma proteins. Am J Clin Nutr 88:1067-1073. https://doi.org/ 10.1093/ajen/88.4.1067

42. Haase H, Rink L (2014) Zinc signals and immune function. BioFactors (Oxford, England) 40:27-40. https://doi.org/10.1002/ biof.1114

43. Bonaventura P, Benedetti G, Albarède F, Miossec P (2015) Zinc and its role in immunity and inflammation. Autoimmun Rev 14:277-285. https://doi.org/10.1016/j.autrev.2014.11.008

44. Skrajnowska D, Bobrowska-Korczak B (2019) Role of zinc in immune system and anti-cancer defense mechanisms. Nutrients. https://doi.org/10.3390/nu11102273

45. Rosenkranz E, Metz CH, Maywald M, Hilgers RD, Weßels I, Senff T, Haase H, Jäger M, Ott M, Aspinall R, Plümäkers B, Rink L (2016) Zinc supplementation induces regulatory T cells by inhibition of Sirt-1 deacetylase in mixed lymphocyte cultures. Mol Nutr Food Res 60:661-671. https://doi.org/10.1002/mnfr. 201500524

46. Wessels I, Maywald M, Rink L (2017) Zinc as a gatekeeper of immune function. Nutrients. https://doi.org/10.3390/nu9121286

47. Maywald M, Meurer SK, Weiskirchen R, Rink L (2017) Zinc supplementation augments TGF- $\beta 1$-dependent regulatory $\mathrm{T}$ cell induction. Mol Nutrit \& Food Res. https://doi.org/10.1002/mnfr. 201600493

48. Bao S, Liu MJ, Lee B, Besecker B, Lai JP, Guttridge DC, Knoell DL (2010) Zinc modulates the innate immune response in vivo to polymicrobial sepsis through regulation of NF-kappaB. Am J Physiol Lung Cell Mol Physiol 298:L744-754. https://doi.org/ 10.1152/ajplung.00368.2009

49. Knoell DL, Smith DA, Sapkota M, Heires AJ, Hanson CK, Smith LM, Poole JA, Wyatt TA, Romberger DJ (2019) Insufficient zinc intake enhances lung inflammation in response to agricultural organic dust exposure. J Nutr Biochem 70:56-64. https://doi.org/ 10.1016/j.jnutbio.2019.04.007

50. Haase H, Schomburg L (2019) You'd better zinc-trace element homeostasis in infection and inflammation. Nutrients. https://doi. org/10.3390/nu11092078

51. Stanford SM, Rapini N, Bottini N (2012) Regulation of TCR signalling by tyrosine phosphatases: from immune homeostasis to autoimmunity. Immunology 137:1-19. https://doi.org/10.1111/j. 1365-2567.2012.03591.x

52. Foronjy RF, Ochieng PO, Salathe MA, Dabo AJ, Eden E, Baumlin N, Cummins N, Barik S, Campos M, Thorp EB, Geraghty $P$ (2016) Protein tyrosine phosphatase 1B negatively regulates S100A9-mediated lung damage during respiratory syncytial virus exacerbations. Mucosal Immunol 9:1317-1329. https:// doi.org/10.1038/mi.2015.138

53. Cakman I, Kirchner H, Rink L (1997) Zinc supplementation reconstitutes the production of interferon-alpha by leukocytes from elderly persons. J Interferon Cytokine Res 17:469-472. https://doi.org/10.1089/jir.1997.17.469 
54. Lin FC, Young HA (2014) Interferons: success in anti-viral immunotherapy. Cytokine Growth Factor Rev 25:369-376. https://doi.org/10.1016/j.cytogfr.2014.07.015

55. Read SA, O'Connor KS, Suppiah V, Ahlenstiel CLE, Obeid S, Cook KM, Cunningham A, Douglas MW, Hogg PJ, Booth D, George J, Ahlenstiel G (2017) Zinc is a potent and specific inhibitor of IFN- $\lambda 3$ signalling. Nat Commun 8:15245. https:// doi.org/10.1038/ncomms 15245

56. Kambe T, Hashimoto A, Fujimoto S (2014) Current understanding of ZIP and ZnT zinc transporters in human health and diseases. Cellular and molecular life sciences : CMLS 71:3281-3295. https://doi.org/10.1007/s00018-014-1617-0

57. Jeong J, Eide DJ (2013) The SLC39 family of zinc transporters. Mol Aspects Med 34:612-619. https://doi.org/10.1016/j.mam. 2012.05.011

58. Bafaro E, Liu Y, Xu Y, Dempski RE (2017) The emerging role of zinc transporters in cellular homeostasis and cancer. Signal Transduct Target Ther 2:17029. https://doi.org/10.1038/sigtr ans.2017.29

59. Kukic I, Kelleher SL, Kiselyov K (2014) Zn2+ efflux through lysosomal exocytosis prevents $\mathrm{Zn} 2+-$ induced toxicity. J Cell Sci 127(14):3094-3103. https://doi.org/10.1242/jcs.145318

60. Liuzzi JP, Cousins RJ (2004) Mammalian zinc transporters. Annu Rev Nutr 24:151-172. https://doi.org/10.1146/annurev. nutr.24.012003.132402

61. Besecker B, Bao S, Bohacova B, Papp A, Sadee W, Knoell DL (2008) The human zinc transporter SLC39A8 (Zip8) is critical in zinc-mediated cytoprotection in lung epithelia. Am J Physiol Lung Cell Mol Physiol 294:L1127-1136. https://doi. org/10.1152/ajplung.00057.2008

62. Zang ZS, Xu YM, Lau ATY (2016) Molecular and pathophysiological aspects of metal ion uptake by the zinc transporter ZIP8 (SLC39A8). Toxicology research 5:987-1002. https:// doi.org/10.1039/c5tx00424a

63. Liu MJ, Bao S, Gálvez-Peralta M, Pyle CJ, Rudawsky AC, Pavlovicz RE, Killilea DW, Li C, Nebert DW, Wewers MD, Knoell DL (2013) ZIP8 regulates host defense through zinc-mediated inhibition of NF-кB. Cell Rep 3:386-400. https://doi.org/10. 1016/j.celrep.2013.01.009

64. Prasad AS (2014) Zinc is an antioxidant and anti-inflammatory agent: its role in human health. Front Nutr 1:14. https://doi.org/ 10.3389/fnut.2014.00014

65. Vasto S, Mocchegiani E, Malavolta M, Cuppari I, Listì F, Nuzzo D, Ditta V, Candore G, Caruso C (2007) Zinc and inflammatory/immune response in aging. Ann N Y Acad Sci 1100:111-122. https://doi.org/10.1196/annals.1395.009

66. Kar M, Khan NA, Panwar A, Bais SS, Basak S, Goel R, Sopory S, Medigeshi GR (2019) Zinc chelation specifically inhibits early stages of dengue virus replication by activation of nf- $\mathrm{\kappa b}$ and induction of antiviral response in epithelial cells. Front Immunol 10:2347. https://doi.org/10.3389/fimmu.2019.02347

67. Wessels I, Pupke JT, von Trotha KT, Gombert A, Himmelsbach A, Fischer HJ, Jacobs MJ, Rink L, Grommes J (2020) Zinc supplementation ameliorates lung injury by reducing neutrophil recruitment and activity. Thorax 75:253-261. https://doi.org/ 10.1136/thoraxjnl-2019-213357

68. Hall SC, Smith DR, Katafiasz DM, Bailey KL, Knoell DL (2019) Novel role of zinc homeostasis in IL-23 regulation and host defense following bacterial infection. J Immunol 202(1):62-66

69. Zalewski PD (2006) Zinc metabolism in the airway: basic mechanisms and drug targets. Curr Opin Pharmacol 6:237-243. https:// doi.org/10.1016/j.coph.2006.01.005

70. Hamon R, Homan CC, Tran HB, Mukaro VR, Lester SE, Roscioli E, Bosco MD, Murgia CM, Ackland ML, Jersmann HP, Lang C, Zalewski PD, Hodge SJ (2014) Zinc and zinc transporters in macrophages and their roles in efferocytosis in COPD. PLoS ONE 9:e110056. https://doi.org/10.1371/journal.pone.0110056

71. Li MM, MacDonald MR, Rice CM (2015) To translate, or not to translate: viral and host mRNA regulation by interferon-stimulated genes. Trends Cell Biol 25:320-329. https://doi.org/10. 1016/j.tcb.2015.02.001

72. Li MMH, Aguilar EG, Michailidis E, Pabon J, Park P, Wu X, de Jong YP, Schneider WM, Molina H, Rice CM, MacDonald MR (2019) Characterization of novel splice variants of zinc finger antiviral protein (ZAP). J Virol. https://doi.org/10.1128/jvi. 00715-19

73. Ficarelli M, Wilson H, Pedro Galão R, Mazzon M, AntzinAnduetza I, Marsh M, Neil SJ, Swanson CM (2019) KHNYN is essential for the zinc finger antiviral protein (ZAP) to restrict HIV-1 containing clustered CpG dinucleotides. Elife. https://doi. org/10.7554/eLife.46767

74. Parvatiyar K, Harhaj EW (2011) Regulation of inflammatory and antiviral signaling by A20. Microbes Infect 13:209-215. https:// doi.org/10.1016/j.micinf.2010.11.003

75. Arguello M, Paz S, Ferran C, Moll HP, Hiscott J (2014) Antiviral tetris: modulation of the innate anti-viral immune response by A20. Adv Exp Med Biol 809:49-64. https://doi.org/10.1007/ 978-1-4939-0398-6_4

76. Shembade N, Ma A, Harhaj EW (2010) Inhibition of NF-kappaB signaling by A20 through disruption of ubiquitin enzyme complexes. Science (New York, NY) 327:1135-1139. https://doi.org/ 10.1126/science. 1182364

77. Saitoh T, Yamamoto M, Miyagishi M, Taira K, Nakanishi M, Fujita T, Akira S, Yamamoto N, Yamaoka S (2005) A20 is a negative regulator of IFN regulatory factor 3 signaling. J Immunol 174:1507-1512. https://doi.org/10.4049/jimmunol.174.3. 1507

78. Ma A, Malynn BA (2012) A20: linking a complex regulator of ubiquitylation to immunity and human disease. Nat Rev Immunol 12:774-785. https://doi.org/10.1038/nri3313

79. Maelfait J, Roose K, Vereecke L, Mc Guire C, Sze M, Schuijs MJ, Willart M, Ibañez LI, Hammad H, Lambrecht BN, Beyaert R, Saelens X, van Loo G (2016) A20 deficiency in lung epithelial cells protects against influenza A virus infection. PLoS Pathog 12:e1005410. https://doi.org/10.1371/journal.ppat.1005410

80. Martín-Vicente M, González-Sanz R, Cuesta I, Monzón S, Resino S, Martínez I (2020) Downregulation of A20 expression increases the immune response and apoptosis and reduces virus production in cells infected by the human respiratory syncytial virus. Vaccines. https://doi.org/10.3390/vaccines 8010100

81. Prasad AS (2013) Discovery of human zinc deficiency: its impact on human health and disease. Advances in nutrition (Bethesda, Md) 4:176-190. https://doi.org/10.3945/an.112.003210

82. Haase H, Rink L (2009) Functional significance of zinc-related signaling pathways in immune cells. Annu Rev Nutr 29:133-152. https://doi.org/10.1146/annurev-nutr-080508-141119

83. Morgan CI, Ledford JR, Zhou P, Page K (2011) Zinc supplementation alters airway inflammation and airway hyperresponsiveness to a common allergen. J Inflammation (London, England) 8:36. https://doi.org/10.1186/1476-9255-8-36

84. Ishida $\mathrm{T}$ (2019) Review on the role of $\mathrm{Zn} 2+$ ions in viral pathogenesis and the effect of $\mathrm{Zn} 2+$ ions for host cell-virus growth inhibition. Am J Biomed Sci Res 2:28-37

85. Fu B, Wang L, Li S, Dorf ME (2017) ZMPSTE24 defends against influenza and other pathogenic viruses. J Exp Med 214:919-929. https://doi.org/10.1084/jem.20161270

86. Kudchodkar SB, Levine B (2009) Viruses and autophagy. Rev Med Virol 19:359-378. https://doi.org/10.1002/rmv.630

87. Hwang JJ, Kim HN, Kim J, Cho DH, Kim MJ, Kim YS, Kim Y, Park SJ, Koh JY (2010) Zinc(II) ion mediates tamoxifeninduced autophagy and cell death in MCF-7 breast cancer 
cell line. Biometals 23:997-1013. https://doi.org/10.1007/ s10534-010-9346-9

88. Hung HH, Huang WP, Pan CY (2013) Dopamine- and zincinduced autophagosome formation facilitates PC12 cell survival. Cell Biol Toxicol 29:415-429. https://doi.org/10.1007/ s10565-013-9261-2

89. Liuzzi JP, Yoo C (2013) Role of zinc in the regulation of autophagy during ethanol exposure in human hepatoma cells. Biol Trace Elem Res 156:350-356. https://doi.org/10.1007/ s12011-013-9816-3

90. Moghadami M (2017) A narrative review of influenza: a seasonal and pandemic disease. Iranian J Med Sci 42:2-13

91. Denney L, Ho LP (2018) The role of respiratory epithelium in host defence against influenza virus infection. Biomed J 41:218-233. https://doi.org/10.1016/j.bj.2018.08.004

92. Saunders-Hastings PR, Krewski D (2016) Reviewing the History of pandemic influenza: understanding patterns of emergence and transmission. Pathogens 5(4):66. https://doi.org/10. 3390/pathogens5040066

93. Chaisri U, Chaicumpa W (2018) Evolution of therapeutic antibodies, influenza virus biology, influenza, and influenza immunotherapy. Biomed Res Int 2018:9747549. https://doi. org/10.1155/2018/9747549

94. Zheng B, Zhou J, Wang H (2020) Host microRNAs and exosomes that modulate influenza virus infection. Virus Res 279:197885. https://doi.org/10.1016/j.virusres.2020.197885

95. Bouvier NM, Palese P (2008) The biology of influenza viruses. Vaccine 26:49-53. https://doi.org/10.1016/j.vaccine.2008.07. 039

96. Te Velthuis AJ, Fodor E (2016) Influenza virus RNA polymerase: insights into the mechanisms of viral RNA synthesis. Nat Rev Microbiol 14:479-493. https://doi.org/10.1038/nrmicro.2016.87

97. Hutchinson EC, Fodor E (2013) Transport of the influenza virus genome from nucleus to nucleus. Viruses 5:2424-2446. https:// doi.org/10.3390/v5102424

98. Vogel OA, Manicassamy B (2020) Broadly protective strategies against influenza viruses: universal vaccines and therapeutics. Front Microbiol 11:135. https://doi.org/10.3389/fmicb.2020. 00135

99. Germeraad EA, Sanders P, Hagenaars TJ, Jong MCM, Beerens $\mathrm{N}$, Gonzales JL (2019) Virus shedding of avian influenza in poultry: a systematic review and meta-analysis. Viruses 11(9):812. https://doi.org/10.3390/v11090812

100. Guarner J, Falcón-Escobedo R (2009) Comparison of the pathology caused by H1N1, H5N1, and H3N2 influenza viruses. Arch Med Res 40:655-661. https://doi.org/10.1016/j.arcmed.2009.10. 001

101. Samji T (2009) Influenza A: understanding the viral life cycle. Yale J Biol Med 82:153-159

102. Zeng LY, Yang J, Liu S (2017) Investigational hemagglutinintargeted influenza virus inhibitors. Expert Opin Investig Drugs 26:63-73. https://doi.org/10.1080/13543784.2017.1269170

103. Edinger TO, Pohl MO, Stertz S (2014) Entry of influenza A virus: host factors and antiviral targets. J Gen Virol 95:263-277. https://doi.org/10.1099/vir.0.059477-0

104. Mair CM, Ludwig K, Herrmann A, Sieben C (2014) Receptor binding and $\mathrm{pH}$ stability - how influenza A virus hemagglutinin affects host-specific virus infection. Biochem Biophys Acta 1838:1153-1168. https://doi.org/10.1016/j.bbamem.2013.10.004

105. Dou D, Revol R, Östbye H, Wang H, Daniels R (2018) Influenza A virus cell entry, replication, virion assembly and movement. Front Immunol 9:1581. https://doi.org/10.3389/fimmu.2018. 01581

106. Smrt ST, Lorieau JL (2017) Membrane fusion and infection of the influenza hemagglutinin. Adv Exp Med Biol 966:37-54. https://doi.org/10.1007/5584_2016_174
107. Zhao M, Wang L, Li S (2017) Influenza A virus-host protein interactions control viral pathogenesis. Int J Mol Sci 18(8):1673. https://doi.org/10.3390/ijms18081673

108. Rossman JS, Lamb RA (2011) Influenza virus assembly and budding. Virology 411(2):229-236. https://doi.org/10.1016/j. virol.2010.12.003

109. Guo XJ, Thomas PG (2017) New fronts emerge in the influenza cytokine storm. Seminars Immunopathol 39:541-550. https:// doi.org/10.1007/s00281-017-0636-y

110. Chen X, Liu S, Goraya MU, Maarouf M, Huang S, Chen JL (2018) Host Immune response to influenza A virus infection. Front Immunol 9:320. https://doi.org/10.3389/fimmu.2018. 00320

111. Latino I, Gonzalez SF (2021) Spatio-temporal profile of innate inflammatory cells and mediators during influenza virus infection. Curr Opin Physio 19:175-186. https://doi.org/10.1016/j. cophys.2020.10.008

112. Liu Q, Zhou YH, Yang ZQ (2016) The cytokine storm of severe influenza and development of immunomodulatory therapy. Cell Mol Immunol 13:3-10. https://doi.org/10.1038/cmi.2015.74

113. Kreijtz JH, Fouchier RA, Rimmelzwaan GF (2011) Immune responses to influenza virus infection. Virus Res 162:19-30. https://doi.org/10.1016/j.virusres.2011.09.022

114. Park JK, Xiao Y, Ramuta MD, Rosas LA, Fong S, Matthews AM, Freeman AD, Gouzoulis MA, Batchenkova NA, Yang X, Scherler K, Qi L, Reed S, Athota R, Czajkowski L, Han A, Morens DM, Walters KA, Memoli MJ, Kash JC, Taubenberger JK (2020) Pre-existing immunity to influenza virus hemagglutinin stalk might drive selection for antibody-escape mutant viruses in a human challenge model. Nat Med 26:1240-1246. https://doi.org/10.1038/s41591-020-0937-x

115. Ghaffari H, Tavakoli A, Moradi A, Tabarraei A, BokharaeiSalim F, Zahmatkeshan M, Farahmand M, Javanmard D, Kiani SJ, Esghaei M, Pirhajati-Mahabadi V, Monavari SH, AtaeiPirkooh A (2019) Inhibition of H1N1 influenza virus infection by zinc oxide nanoparticles: another emerging application of nanomedicine. J Biomed Sci 26:70. https://doi.org/10.1186/ s12929-019-0563-4

116. Oxford JS, Perrin DD (1974) Inhibition of the particle-associated RNA-dependent RNA polymerase activity of influenza viruses by chelating agents. J Gen Virol 23:59-71. https://doi. org/10.1099/0022-1317-23-1-59

117. Lin RJ, Huang CH, Liu PC, Lin IC, Huang YL, Chen AY, Chiu HP, Shih SR, Lin LH, Lien SP, Yen LC, Liao CL (2020) Zinc finger protein ZFP36L1 inhibits influenza A virus through translational repression by targeting HA, M and NS RNA transcripts. Nucleic Acids Res 48:7371-7384. https://doi.org/10. 1093/nar/gkaa458

118. Pyo CW, Shin N, Jung KI, Choi JH, Choi SY (2014) Alteration of copper-zinc superoxide dismutase 1 expression by influenza A virus is correlated with virus replication. Biochem Biophys Res Commun 450:711-716. https://doi.org/10.1016/j.bbrc. 2014.06.037

119. Zhang B, Goraya MU, Chen N, Xu L, Hong Y, Zhu M, Chen JL (2020) Zinc finger CCCH-type antiviral protein 1 Restricts the viral replication by positively regulating type I interferon response. Front Microbiol 11:1912. https://doi.org/10.3389/ fmicb.2020.01912

120. Welliver RC (2003) Review of epidemiology and clinical risk factors for severe respiratory syncytial virus (RSV) infection. J Pediatr 143(5 Suppl):S112-117. https://doi.org/10.1067/s00223476(03)00508-0

121. Hall CB (2001) Respiratory syncytial virus and parainfluenza virus. N Engl J Med 344:1917-1928. https://doi.org/10.1056/ nejm200106213442507 
122. Welliver RC (2003) Respiratory syncytial virus and other respiratory viruses. The Pediatric Infect Disease J 22(2):6-10. https://doi.org/10.1097/01.inf.0000053880.92496.db

123. Jung HE, Kim TH, Lee HK (2020) Contribution of dendritic cells in protective immunity against respiratory syncytial virus infection. Viruses 12(1):102. https://doi.org/10.3390/v1201 0102

124. McLellan JS, Ray WC, Peeples ME (2013) Structure and function of respiratory syncytial virus surface glycoproteins. Curr Top Microbiol Immunol 372:83-104. https://doi.org/10.1007/ 978-3-642-38919-1_4

125. Ghildyal R, Ho A, Jans DA (2006) Central role of the respiratory syncytial virus matrix protein in infection. FEMS Microbiol Rev 30:692-705. https://doi.org/10.1111/j.1574-6976.2006.00025.x

126. Cowton VM, McGivern DR, Fearns R (2006) Unravelling the complexities of respiratory syncytial virus RNA synthesis. J Gen Virol 87:1805-1821. https://doi.org/10.1099/vir.0.81786-0

127. Russell CD, Unger SA, Walton M, Schwarze J (2017) The human immune response to respiratory syncytial virus infection. Clin Microbiol Rev 30:481-502. https://doi.org/10.1128/ cmr.00090-16

128. Welliver RC, Sun M, Rinaldo D, Ogra PL (1985) Respiratory syncytial virus-specific IgE responses following infection: evidence for a predominantly mucosal response. Pediatr Res 19:420-424. https://doi.org/10.1203/00006450-19850 5000-00002

129. Stier MT, Bloodworth MH, Toki S, Newcomb DC, Goleniewska K, Boyd KL, Quitalig M, Hotard AL, Moore ML, Hartert TV, Zhou B, McKenzie AN, Peebles RS Jr (2016) Respiratory syncytial virus infection activates IL-13-producing group 2 innate lymphoid cells through thymic stromal lymphopoietin. J Allergy Clin Immunol 138(814-824):e811. https://doi.org/10.1016/j.jaci. 2016.01.050

130. Wu YH, Lai AC, Chi PY, Thio CL, Chen WY, Tsai CH, Lee YL, Lukacs NW, Chang YJ (2020) Pulmonary IL-33 orchestrates innate immune cells to mediate respiratory syncytial virus-evoked airway hyperreactivity and eosinophilia. Allergy 75:818-830. https://doi.org/10.1111/all.14091

131. Han M, Rajput C, Hong JY, Lei J, Hinde JL, Wu Q, Bentley JK, Hershenson MB (2017) The innate cytokines IL-25, IL-33, and TSLP cooperate in the induction of type 2 innate lymphoid cell expansion and mucous metaplasia in rhinovirus-infected immature mice. J Immunol 199:1308-1318. https://doi.org/10.4049/ jimmunol.1700216

132. Drake LY, Kita H (2017) IL-33: biological properties, functions, and roles in airway disease. Immunol Rev 278:173-184. https:// doi.org/10.1111/imr.12552

133. Soto JA, Stephens LM, Waldstein KA, Canedo-Marroquín G, Varga SM, Kalergis AM (2020) Current insights in the development of efficacious vaccines against RSV. Front Immunol 11:1507. https://doi.org/10.3389/fimmu.2020.01507

134. Eiland LS (2009) Respiratory syncytial virus: diagnosis, treatment and prevention. J Pediatric Pharmacol Therapeutics 14:7585. https://doi.org/10.5863/1551-6776-14.2.75

135. Gupta S, Read SA, Shackel NA, Hebbard L, George J, Ahlenstiel G (2019) The Role of micronutrients in the infection and subsequent response to hepatitis $\mathrm{C}$ virus. Cells 8(6):603. https://doi. org/10.3390/cells 8060603

136. Alexander J, Tinkov A, Strand TA, Alehagen U, Skalny A, Aaseth J (2020) Early nutritional interventions with zinc, selenium and vitamin $\mathrm{D}$ for raising anti-viral resistance against progressive COVID-19. Nutrients 12(8):2358. https://doi.org/10. 3390/nu12082358

137. Che Z, Sun J (2016) Investigation on relationship between whole blood zinc and Fe elements with children pneumonia caused by respiratory syncytial virus. Int J Lab Med 37(2401-2402):2405
138. Suara RO, Crowe JE Jr (2004) Effect of zinc salts on respiratory syncytial virus replication. Antimicrob Agents Chemother 48:783-790. https://doi.org/10.1128/aac.48.3.783-790.2004

139. Saigal P, Hanekom D (2020) Does zinc improve symptoms of viral upper respiratory tract infection? Evidence-Based Practice 23:37-39

140. Johnson JK, Harris FL, Ping XD, Gauthier TW, Brown LAS (2019) Role of zinc insufficiency in fetal alveolar macrophage dysfunction and RSV exacerbation associated with fetal ethanol exposure. Alcohol (Fayetteville, NY) 80:5-16. https://doi.org/ 10.1016/j.alcohol.2018.11.007

141. Zhou Y, Hou Y, Shen J, Huang Y, Martin W, Cheng F (2020) Network-based drug repurposing for novel coronavirus 2019nCoV/SARS-CoV-2. Cell discovery 6(1):14. https://doi.org/10. 1038/s41421-020-0153-3

142. Wu C, Liu Y, Yang Y, Zhang P, Zhong W, Wang Y, Wang Q, Xu Y, Li M, Li X, Zheng M, Chen L, Li H (2020) Analysis of therapeutic targets for SARS-CoV-2 and discovery of potential drugs by computational methods. Acta pharmaceutica Sinica B 10:766-788. https://doi.org/10.1016/j.apsb.2020.02.008

143. Momtazi-Borojeni AA, Banach M, Reiner Ž, Pirro M, Bianconi V, Al-Rasadi K, Sahebkar A (2021) Interaction between coronavirus S-protein and human ACE2: hints for exploring efficient therapeutic targets to treat COVID-19. Angiology 72:122-130. https://doi.org/10.1177/0003319720952284

144. Lee C, Choi WJ (2021) Overview of COVID-19 inflammatory pathogenesis from the therapeutic perspective. Arch Pharmacal Res 44:99-116. https://doi.org/10.1007/s12272-020-01301-7

145. Yazdanpanah F, Hamblin MR, Rezaei N (2020) The immune system and COVID-19: friend or foe? Life Sci 256:117900. https:// doi.org/10.1016/j.lfs.2020.117900

146. Giamarellos-Bourboulis EJ, Netea MG, Rovina N, Akinosoglou $\mathrm{K}$, Antoniadou A, Antonakos N, Damoraki G, Gkavogianni T, Adami ME, Katsaounou P, Ntaganou M, Kyriakopoulou M, Dimopoulos G, Koutsodimitropoulos I, Velissaris D, Koufargyris P, Karageorgos A, Katrini K, Lekakis V, Lupse M, Kotsaki A, Renieris G, Theodoulou D, Panou V, Koukaki E, Koulouris N, Gogos C, Koutsoukou A (2020) Complex immune dysregulation in COVID-19 patients with severe respiratory failure. Cell Host Microbe 27(992-1000):e1003. https://doi.org/10.1016/j.chom. 2020.04.009

147. Han YS, Chang GG, Juo CG, Lee HJ, Yeh SH, Hsu JT, Chen X (2005) Papain-like protease 2 (PLP2) from severe acute respiratory syndrome coronavirus (SARS-CoV): expression, purification, characterization, and inhibition. Biochemistry 44:1034910359. https://doi.org/10.1021/bi0504761

148. Jothimani D, Kailasam E, Danielraj S, Nallathambi B, Ramachandran H, Sekar P, Manoharan S, Ramani V, Narasimhan G, Kaliamoorthy I, Rela M (2020) COVID-19: poor outcomes in patients with zinc deficiency. Int J Infect Diseases 100:343-349. https://doi.org/10.1016/j.ijid.2020.09.014

149. Anuk AT, Polat N, Akdas S, Erol SA, Tanacan A, Biriken D, Keskin HL, Moraloglu Tekin O, Yazihan N, Sahin D (2020) The relation between trace element status (zinc, copper, magnesium) and clinical outcomes in COVID-19 infection during pregnancy. Biol Trace Element Res. https://doi.org/10.1007/ s12011-020-02496-y

150. Heller RA, Sun Q, Hackler J, Seelig J, Seibert L, Cherkezov A, Minich WB, Seemann P, Diegmann J, Pilz M, Bachmann M, Ranjbar A, Moghaddam A, Schomburg L (2021) Prediction of survival odds in COVID-19 by zinc, age and selenoprotein $\mathrm{P}$ as composite biomarker. Redox Biol 38:101764. https://doi.org/10. 1016/j.redox.2020.101764

151. Frontera JA, Rahimian JO, Yaghi S, Liu M, Lewis A, de Havenon A, Mainali S, Huang J, Scher E, Wisniewski T, Troxel AB, Meropol S, Balcer LJ, Galetta SL (2020) Treatment with zinc is 
associated with reduced in-hospital mortality among COVID-19 patients: a multi-center cohort study. Res Square. https://doi.org/ 10.21203/rs.3.rs-94509/v1

152. Carlucci PM, Ahuja T, Petrilli C, Rajagopalan H, Jones S, Rahimian J (2020) Zinc sulfate in combination with a zinc ionophore may improve outcomes in hospitalized COVID-19 patients. J Med Microbiol 69:1228-1234. https://doi.org/10. 1099/jmm.0.001250

153. Derwand R, Scholz M, Zelenko V (2020) COVID-19 outpatients: early risk-stratified treatment with zinc plus low-dose hydroxychloroquine and azithromycin: a retrospective case series study. Int J Antimicrob Agents 56:106214. https://doi.org/10.1016/j. ijantimicag.2020.106214

154. Yao JS, Paguio JA, Dee EC, Tan HC, Moulick A, Milazzo C, Jurado J, Della Penna N, Celi LA (2021) The minimal effect of zinc on the survival of hospitalized patients with COVID-19: an observational study. Chest 159:108-111. https://doi.org/10. 1016/j.chest.2020.06.082

155. Abd-Elsalam S, Soliman S, Esmail ES, Khalaf M, Mostafa EF, Medhat MA, Ahmed OA, El Ghafar MSA, Alboraie M, Hassany SM (2020) Do zinc supplements enhance the clinical efficacy of hydroxychloroquine?: a randomized, multicenter trial. Biol Trace Elem Res. https://doi.org/10.1007/s12011-020-02512-1

156. Elalfy H, Besheer T, El-Mesery A, El-Gilany AH, Soliman MA, Alhawarey A, Alegezy M, Elhadidy T, Hewidy AA, Zaghloul H, Neamatallah MAM, Raafat D, El-Emshaty WM, Abo El Kheir NY, El-Bendary M (2021) Effect of a combination of nitazoxanide, ribavirin, and ivermectin plus zinc supplement (MANS. NRIZ study) on the clearance of mild COVID-19. J Med Virol 93:3176-3183. https://doi.org/10.1002/jmv.26880

157. Linko R, Karlsson S, Pettilä V, Varpula T, Okkonen M, Lund V, Ala-Kokko T, Ruokonen E (2011) Serum zinc in critically ill adult patients with acute respiratory failure. Acta Anaesthesiol Scand 55:615-621. https://doi.org/10.1111/j.1399-6576.2011. 02425.x

158. Boudreault F, Pinilla-Vera M, Englert JA, Kho AT, Isabelle C, Arciniegas AJ, Barragan-Bradford D, Quintana C, AmadorMunoz D, Guan J, Choi KM, Sholl L, Hurwitz S, Tschumperlin DJ, Baron RM (2017) Zinc deficiency primes the lung for ventilator-induced injury. JCI insight. https://doi.org/10.1172/jci. insight. 86507

159. Mahalanabis D, Lahiri M, Paul D, Gupta S, Gupta A, Wahed MA, Khaled MA (2004) Randomized, double-blind, placebocontrolled clinical trial of the efficacy of treatment with zinc or vitamin $\mathrm{A}$ in infants and young children with severe acute lower respiratory infection. Am J Clin Nutr 79:430-436. https://doi. org/10.1093/ajen/79.3.430

160. Hashemian H, Alizadeh H, Kazemnejad Leyli E (2020) Efficacy of zinc as adjuvant therapy in the treatment of severe pneumonia in hospitalized children: a randomized clinical trial. Arch Pediatr Infect Dis 9:e105318. https://doi.org/10.5812/pedinfect.105318

161. Fang L, Roth M, S'Ng CT, Tamm M, Han B, Hoang BX (2020) Zinc salicylate reduces airway smooth muscle cells remodelling by blocking mTOR and activating p21((Waf1/Cip1)). J Nutr
Biochem 89:108563. https://doi.org/10.1016/j.jnutbio.2020. 108563

162. Gonçalves TJM, Gonçalves S, Guarnieri A, Risegato RC, Guimarães MP, de Freitas DC, Razuk-Filho A, Junior PBB, Parrillo EF (2020) Association between low zinc levels and severity of acute respiratory distress syndrome by new coronavirus (SARSCoV-2). Nutr Clin Pract. https://doi.org/10.1002/ncp.10612

163. Wu DQ, Wu HB, Zhang M, Wang JA (2017) Effects of zinc finger protein A20 on lipopolysaccharide (LPS)-induced pulmonary inflammation/anti-inflammatory mediators in an acute lung injury/acute respiratory distress syndrome rat model. Med Sci Monitor 23:3536-3545. https://doi.org/10.12659/msm.901700

164. Wang Z, Burwinkel M, Chai W, Lange E, Blohm U, Breithaupt A, Hoffmann B, Twardziok S, Rieger J, Janczyk P, Pieper R, Osterrieder N (2014) Dietary Enterococcus faecium NCIMB 10415 and zinc oxide stimulate immune reactions to trivalent influenza vaccination in pigs but do not affect virological response upon challenge infection. PLoS ONE 9:e87007. https:// doi.org/10.1371/journal.pone.0087007

165. Yalçın SS, Engür-Karasimav D, Alehan D, Yurdakök K, Ozkutlu S, Coşkun T (2011) Zinc supplementation and TNF- $\alpha$ levels in vaccinated cardiac patients. J Trace Elements Med Biol 25:8590. https://doi.org/10.1016/j.jtemb.2011.03.002

166. Provinciali M, Montenovo A, Di Stefano G, Colombo M, Daghetta L, Cairati M, Veroni C, Cassino R, Della Torre F, Fabris N (1998) Effect of zinc or zinc plus arginine supplementation on antibody titre and lymphocyte subsets after influenza vaccination in elderly subjects: a randomized controlled trial. Age Ageing 27:715-722. https://doi.org/10.1093/ageing/27.6.715

167. Bracker MD, Hollingsworth JW, Saltman PD, Strause LG, Klauber MR, Lugo NJ (1988) Failure of dietary zinc supplementation to improve the antibody response to influenza vaccine. Nutr Res 8:99-104. https://doi.org/10.1016/S0271-5317(88)80093-9

168. Sundaram ME, Meydani SN, Vandermause M, Shay DK, Coleman LA (2014) Vitamin E, vitamin A, and zinc status are not related to serologic response to influenza vaccine in older adults: an observational prospective cohort study. Nutrition Research (New York, NY) 34:149-154. https://doi.org/10.1016/j.nutres. 2013.12.004

169. Palomares RA, Hurley DJ, Bittar JH, Saliki JT, Woolums AR, Moliere F, Havenga LJ, Norton NA, Clifton SJ, Sigmund AB, Barber CE, Berger ML, Clark MJ, Fratto MA (2016) Effects of injectable trace minerals on humoral and cell-mediated immune responses to Bovine viral diarrhea virus, bovine herpes virus 1 and bovine respiratory syncytial virus following administration of a modified-live virus vaccine in dairy calves. Vet Immunol Immunopathol 178:88-98. https://doi.org/10.1016/j.vetimm. 2016.07.003

Publisher's Note Springer Nature remains neutral with regard to jurisdictional claims in published maps and institutional affiliations. 